COLLOQUIA THEOLOGICA OTTONIANA 2 (2019), s. 153-157

DOI: $10.18276 /$ cto.2019.2-08

\title{
REPORT ON THE 11TH POLISH PHILOSOPHICAL CONGRESS IN LUBLIN
}

\author{
Krzysztof Jaworski* \\ Uniwersytet Szczeciński \\ Instytut Nauk Teologicznych
}

On September 9-14, 2019, the 11th Polish Philosophical Congress at the John Paul II Catholic University of Lublin was held. The meeting was organized by the Faculty of Philosophy of the Catholic University of Lublin, and co-organized by the Committee of Philosophical Sciences of the Polish Academy of Sciences and the Polish Philosophical Society. The event was held under the honorary patronage of the President of the Republic of Poland Andrzej Duda. Monika Walczak, dean of the Faculty of Philosophy of the Catholic University of Lublin was appointed the Chair of the Program Committee, while the Organizing Committee was headed by Marek Lechniak, director of the Institute of Philosophy of the Catholic University of Lublin. Event sponsors included, among others, the Marshall of the Lubelskie Voivodship and the Department of Strategy and Investor Service of the Lublin City Hall. The Philosophical Congress also enjoyed the interest of the media, which included, in particular, TVP3 Lublin, Polish Radio Lublin, Radio Plus, Dziennik Wschodni and the magazine "Filozofuj!".

The tradition of the Philosophical Congresses dates back to the interwar period. The first Congress took place in 1923 in Lviv, and then in 1927 (Warsaw) and 1936 (Cracov). Owing to the war and adverse circumstances in post-war Poland, the next Congress could take place only after four decades, in 1977 in Lublin. The next two conventions were held irregularly in 1987 (Cracov) and 1995 (Torun), and since 2004 the principle of a four-year interval between successive meetings

* Krzysztof Jaworski - Doctor of Philosophy, logician, graduate of the John Paul II Catholic University of Lublin, assistant professor in the Institute of Theological Sciences of the University of Szczecin. Address: ul. Pawła VI 2, 71-459 Szczecin, e-mail: krzysztof.jaworski@usz.edu.pl. ORCID: 0000-0001-8311-780X. 
(2004, 2008, 2012) has been adopted, except for the tenth anniversary congress, which took place in 2015 in Poznan.

Each Polish Philosophical Congress is a great feast of philosophy, where the vast majority of Polish wisdom lovers gather. This feast has a double dimension: personal and scientific. First of all, it is an opportunity to meet and integrate. Contrary to appearances, this is an important aspect of these meetings. Personal knowledge of each other often results in joint scholars' projects which give birth to valuable scientific results. Secondly, the congress is an intellectual feast consisting of numerous lectures and panels. There were about 650 participants from 110 scientific and research centers from Poland and Europe as well as from China and Japan who took part in the 11th Polish Philosophical Congress. Owing to such a large number of participants, the Congress proceeded in twenty different sections: Section of Philosophical Anthropology, Section of Didactics of Philosophy, Section of Epistemology and Metaphilosophy, Section of General Ethics, Section of Detailed and Applied Ethics, Section of Philosophy of Culture, Section of Philosophy of Nature and Philosophy of Natural Sciences, Section of Philosophy of Religion, Section of Philosophy of Society, Law and Politics, Section of Philosophy of Art and Aesthetics, Section of Philosophy of Technic, Section of Philosophy of Mind and Cognitive Science, Foreign Guests Section, Section of History of Modern and Contemporary Philosophy, Section of History of Polish Philosophy, Section of History of Ancient and Medieval Philosophy, Section of Logic, Section of Methodology and Philosophy of Science, Section of Ontology and Metaphysics, Section of Semiotics and the Philosophy of Language. Every day there were also plenary lectures (given by: Jacek Jadacki, Peter Simons, Renata Ziemińska, Elżbieta Jung, Tomasz Żuradzki, Lesław Hostyński and Stanisław Judycki).

The ceremonial opening of the 11th Polish Philosophical Congress took place on Monday, September 9 at 15:00 in the Stefan Cardinal Wyszyński Hall of the Main Building of the Catholic University of Lublin. Inaugural lecture entitled "The puzzle of causality" was delivered by Jacek Jadacki. The lecture was an analysis of causality relationships. The author's aim was to show that indeed there are many concepts of causality. He tried to analyze the relationships between these concepts. It shed new light on the age-old philosophical disputes regarding causality, determinism and creationism. After the inaugural lecture, there was a lively concert by the group Caravana Banda, which took the audience into the world of Balkan music. The first day of the congress ended with a gala dinner for all participants at the John Paul II Collegium. 
The program of the consecutive days of the symposium was tight and included the following blocks:

- plenary lecture (usually in the mornings);

- lectures in individual sections (mornings and afternoons);

- two or three discussion panels (in the afternoons);

- special symposia (at different times of the day).

Apart from that, several accompanying events were organized: Cantata for the four wings of the Enigmatic Theater, Meeting of the Committee of Philosophical Sciences of the Polish Academy of Sciences, Meeting of the Philosophical Section of Lecturers of Catholic Universities, Franciszkański Hofman exhibition, Lublin School of Philosophy exhibition, Fair of Scientific Publishers. There was also an opportunity to receive free archival issues of "Filozofuj" magazine promoting broadly understood philosophy, which was rather a surprise for the invited guests. The magazine is published by the Academicon Publishing House.

Some participants could take meals offered by the organizer, choosing full or half board for an additional fee. Although the organizer did not provide accommodation, a list of recommended places was shared where participants could stay.

All congress events took place at the Main Campus of the Catholic University of Lublin: in the Knowledge Transfer Center, in the Main Building and in the John Paul II Collegium. Each of these buildings was adapted for the needs of the disabled. The speakers could use multimedia projectors and high-class sound system provided in larger rooms.

This synthetic report is impossible to recall all interesting philosophical ideas presented during the symposium. Due to overlapping dates, it was not possible for the same person to attend each lecture. Participants often had to choose one of several competing events. However, one can safely say that the issues of "the whole" philosophy were discussed, even in an interdisciplinary perspective. The detailed program of the 11th Polish Philosophical Congress is available on the event's website ${ }^{1}$. There is also a printed book received by each participant ${ }^{2}$. In addition, each participant was provided a handy material bag, a large and legible ID badge, a briefcase, notebook, pen and printed promotional materials of the Catholic University of Lublin, Lublin City and the Lublin Province.

The crowning event of the 11th Polish Philosophical Congress was a plenary lecture by Stanisław Judycki entitled "Metaphysics and the idea of salvation". The author presented how Western philosophical thought tried to deal with the thesis that if there is no "eternal salvation" after death, then it has to be an "axiological

1 See https://zjazdfilozoficzny.kul.pl/services/program/ [accessed: 7.12.2019].

2 XI Polski Zjazd Filozoficzny. Program, ed. A. Zykubek, Lublin 2019. 
disaster". We want to believe that the world we live in is just a "cradle", the beginning of an infinite life. Judycki asked the question what the eternal life of cognitive, valuing and feeling subjects might be. Judycki's lecture gave an impulse for a lively discussion.

At the end, a summary of the works in thematic sections was held by the presidents or secretaries of the sections. During an hour, it was not only possible to get acquainted with the statistical data on each section (such as the number of speakers, discussants or canceled lectures), but also - depending on the creativity of the reporter - to learn the nature of the works as well as the main ideas presented during the meetings or practical postulates.

The 11th Polish Philosophical Congress held in 2019 at the John Paul II Catholic University of Lublin added important verses on the pages of the book of the Polish philosophical tradition. The organizer fulfilled all his obligations in an exemplary way, by giving participants the opportunity to experience a real intellectual and spiritual feast. As announced, some of the speeches will be included in the special issue of the "Roczniki Filozoficzne" journal published by the Faculty of Philosophy of the Catholic University of Lublin.

The Committee of Philosophical Sciences of the Polish Academy of Sciences and the Main Board of the Polish Philosophical Society have decided to entrust the organization of the next such Congress in 2023 to the Institute of Philosophy of the University of Łódź. It is worth emphasizing that the 12th Polish Philosophical Congress in Łódź will take place exactly on the hundredth anniversary of the 1st Polish Philosophical Congress in Lviv. 


\title{
REPORT ON THE 11TH POLISH PHILOSOPHICAL CONGRESS IN LUBLIN
}

\begin{abstract}
Summary
On September 9-14, the 11th Polish Philosophical Congress was held at the John Paul II Catholic University of Lublin. Conventions of this kind have been a part of the scientific life of Polish philosophers for almost a century. Each meeting is an opportunity to exchange ideas, present the current state of research in the field of philosophy, or integrate the world of Polish philosophers. Initially, this report presents the idea behind Polish philosophical conventions and briefly describes their history. Then, substantive and organizational details of the last congress in Lublin are given. Finally, plans for the next such event are presented.
\end{abstract}

\section{SPRAWOZDANIE Z XI POLSKIEGO ZJAZDU FILOZOFICZNEGO W LUBLINIE}

\section{Streszczenie}

W dniach 9-14 września 2019 roku na Katolickim Uniwersytecie Lubelskim Jana Pawła II odbywał się XI Polski Zjazd Filozoficzny. Tego typu zjazdy od prawie stu lat wpisują się w życie naukowe polskich filozofów. Każde ze spotkań jest okazją do wymiany myśli, prezentacji aktualnego stanu badań z zakresu filozofii, czy też integracji świata polskich filozofów. Niniejsze sprawozdanie w początkowej części wyjaśnia ideę przyświecającą polskim zjazdom filozoficznym oraz przedstawia krótko ich historię. Następnie podane są szczegóły merytoryczne i organizacyjne dotyczące ostatniego zjazdu w Lublinie. Na koniec przedstawiono plany związane z następnym takim wydarzeniem. 